\title{
Public Management Decisions Related to the Decline of California Deer Populations: A Comparative Management Approach
}

\author{
G. Kent Webb \\ College of Business, San Jose State University, USA
}

Copyright $(2016$ by authors, all rights reserved. Authors agree that this article remains permanently open access under the terms of the Creative Commons Attribution License 4.0 International License

\begin{abstract}
Analysis of data obtained from an ongoing internet search indicates that the U.S. deer harvest has been falling since about the year 2000. California has had the largest decline from peak to recent harvest of any state. Declining timber sales are highly correlated with the decline in California. States like California with a relatively high proportion of public land, a low hunter success rate, and a persistently skewed buck-to-doe harvest ratio report a lower harvest as a percent of peak. An economic framework is presented to explain how the public decision making process for deer management and the practice of setting the price of deer hunting licenses well below market equilibrium incentivizes some of these result.
\end{abstract}

Keywords Pricing, Licensing, Rural Economics, Renewable Resources and Conservation, Government Policy

\section{Introduction}

In addition to their intrinsic value as an iconic wildlife species, deer enable multibillion dollar markets related to hunting and tourism. A 2014 U.S. Fish and Wildlife survey [1] estimates that in 2011 big game hunting resulted in $\$ 16.9$ billion in trip-related expenditures, $\$ 9.6$ billion spent on equipment, and that deer hunters were 94 percent of all big game hunters. Total wildlife watching expenditures were about $\$ 55$ billion, although birds were somewhat more popular than mammals. Deer hunting generates more than $\$ 2$ billion annually for the Texas economy [2].

Deer were nearly hunted to extinction by the early 1900's in the United States and were virtually extinct by then in many eastern states. State governments began to manage this resource more carefully and deer populations began to recover. In the East, populations took longer to recover in part because the depth of the decline was more severe. In some parts of the West, where populations were higher near the bottom of their cycle, populations and potential revenue peaked around the 1960's. As deer populations grew, so did management budgets which reinforced strategies designed to increase the population that may have contributed to over population of deer in some regions. Based on analysis of the harvest data, California's deer population peaked at about two million around 1960 [3], falling into the mid-400,000 range by 2013

Data and hypotheses for this research were determined by conducting a daily internet search over several years. Collected data related to state deer management are available at www.deerfriendly.com/decline-of-deer-populations. The results of this analysis indicate that, contrary to much public perception [4], deer populations have been in decline since about the year 2000 in the U.S. and for decades in the West. It is well known that some efforts to protect forests from timber production have resulted in the decline of deer populations. The dramatic decline of the deer harvest in California is highly correlated to the decline of timber sales. In general, deer seem to do better on private land than public land, as measured by current harvest as a percent of peak harvest. In states with more public land, the 2013 harvest is a lower percent of peak harvest. Hunting pressure, as measured by hunter success rates, trend higher in states with more public land. An economic framework presented to explain these circumstances suggests that artificially low prices for deer hunting licenses (tags) may have encouraged over hunting and management strategies that involve short-term population gains, but that are harmful to deer populations in the long-run, for example, the manipulation of the buck-to-doe ratio of the herd. States with deer hunting regulations that persistently result in taking mostly bucks in the hunt have lower current harvests as a percent of peak harvest.

\section{Literature Review and Hypothesis Development}

The decline of deer populations in the Western United 
States over the past many decades is well documented: Ballard [5]; Carpenter [6]; Garton [7]. Although many of the basic factors are understood -- habitat loss and fragmentation, disease, predation, weather - researchers are actively searching for a more complete explanation [8]. Among the public management factors contributing to the decline have been fire suppression and other forest management strategies particularly related to the logging industry. In 2015 Mallicoat [9] comments on "the deplorable state of wildlife habitat in the National Forests." Like many animals, deer do best in edge habitat, the edge of the forest with a mix of trees for cover and meadows for browsing. Long-time, California wildlife biologist Dave Smith [10] attributes the main cause of the decline of the California deer population and other species that thrive in edge habitat to "timber management, but the biggest issue ... is the lack of cleansing wildfires."

Fire suppression has dramatically reduced the cycle of burning down old timber and making way for new growth that provides deer habitat, often suppressing deer populations as reported by Carlson et.al. [11], Clements and Young [12], Kelker [13]. Based on 20 years of observational data, Lowe et al. [14] observed that "Deer summer-fall use declined the first year after fire, but then increased to levels approaching 2.5 times the control through the rest of the 20 -year evaluation period." The beneficial effect of fire on deer habitat was reported in 1932 in California by Storer [15].

Logging reproduces some of the effects of the fire cycle by clearing away parts of the mature forest. In 1971 Heyman and Twiss [16] observed that "Timber harvest can yield improved habitat for deer and other wildlife," Nevertheless, Weber and Chen [17] note that "Starting in the late 1980s and early 1990s, Federal forest management policy in the Pacific Northwest began to emphasize habitat protection and reduced the timber harvest on Federal lands." A 2015 press report from Oregon [18] observes "some leading scientists support regeneration harvests to create more very young forests favored by deer and elk, conservation groups have opposed them." The first hypothesis to be tested follows from these observations. The test evaluates the relationship between timber sales, representing logging activity, and the annual deer harvest in California, the state where the decline in the deer harvest has been the most extreme.

\section{H1: The California deer harvest is positively correlated to} timber sales.

A common observation in the popular literature is that deer do better on private rather than public land. Quoting from a 2014 posting of a deer hunter on an internet discussion board [19] : "There's more deer on private ground than public ground by far. Same habitat. The number of hunters is limited, controlled, on private ground." An economic framework supporting this observation and perhaps some factors contributing to public forest management strategies is presented in Figure 1. State agencies typically set the price of a deer hunting tag (license) below the level of supply. An argument in favor of keeping prices for deer tags low has been that since legally deer belong to the people of each state, the state should not charge a high price for use of this resource. Lotteries and other allocation mechanisms are regularly used to limit the number of tags issued: Sandrey et al. [20], Hussain and Tschirhart [21], Roach et al. [22]. Wildlife managers who allocate the tags do not have authority to raise prices, but by increasing the number of tags can often increase revenue to their department. This circumstance creates an incentive to issue a large number of tags. During the 1960s in Idaho many citizens of the state believed that managers were issuing too many tags causing a significant decline in the deer herd and leading to public controversy Dovel [23].

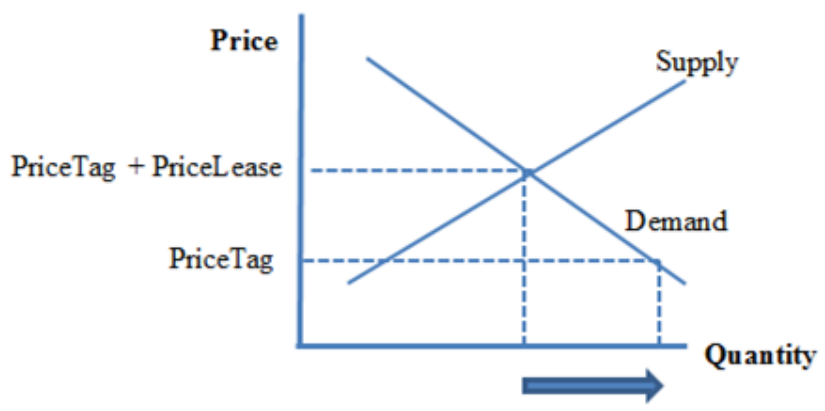

Figure 1. Economic Analysis of Pricing for Deer Hunting Tags

Supply on public and private land can be increased by habitat management, usually requiring some investment. On private land, the landowner can charge a price to lease the land for hunting and can restrict access so that the demand and supply approximately clear at the market price. Curtis and Lynch [24] created an econometric model of deer preferences in Maryland, but did not estimate specific supply and demand functions. State agencies sometimes hold limited auctions of desirable tags to capture some of the revenue that has been left in the market by the pricing policy described in Figure 1. In 2015, a hunting guide paid $\$ 390,000$ for a tag to hunt one mule deer buck on Antelope Island in Utah [25]. Generally, price constrained revenue from hunting on public land is far below potential revenue: Pope and Stoll [26]; Knoche and Lupi [27], Shrestha and Alavalapati [28]; Zhang et al. [29]. This revenue that could be invested in wildlife management and habitat improvement is not captured, often resulting in less investment in habitat improvement on public than on private land.

Hypothesis 2 is derived from this analysis that explains why deer might be expected to do better on private than public land. To formulate this hypothesis in a way that can be tested with the available data, it is suggested that: percent of peak harvest is lower in states with more public land. Hypothesis 3 also follows from this analysis, that hunter success will be lower on states with more public land given the incentive to issue more tags which reduces the success rates for individual hunters. This also suggests Hypothesis 4, that as a result of hunting pressure, the percent of peak harvest will be lower in states with lower hunter success. 
H2: The percent of peak harvest is lower in States with more public land.

H3: Hunter success (number of deer taken per hunter) is lower in states with more public land.

H4: The percent of peak harvest is lower in states with lower hunter success.

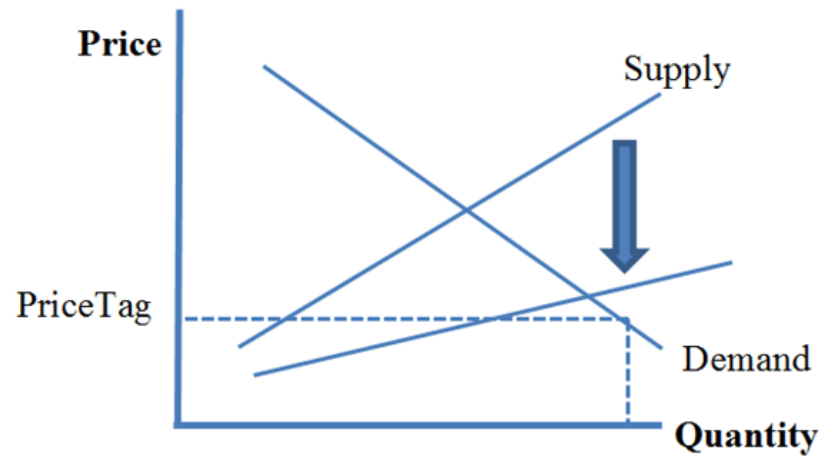

Figure 2. Restricting doe tags, a low cost strategy for increasing future deer supply

A popular low-cost strategy for increasing the deer harvest has been the restriction of doe tags (licenses). During the rebuilding of the deer herds in the early and mid-twentieth century, this was a common practice. Since a buck can breed many does, wildlife agencies focused hunting pressure on bucks, leaving the does to reproduce and increase the population. Figure 2 expresses this strategy in an economic framework. Supply can be inexpensively increased by issuing more buck tags relative to the number of doe tags. Deer appear to have evolved a similar strategy on their own as a way of increasing reproduction after a population decline. Research by Richter and Labisky [30] indicates that deer will produce more females than males when under strong hunting pressure.

Some of the deer overpopulation problems historically experienced in parts of the country is thought to have been a result of pursuing this strategy to a point where many deer hunters considered it a sin to kill a doe. A trend of modern deer management has been, however, to balance herd demographics given a wide perception among deer managers that skewed demographics can be harmful to herd health [31]. An experienced Wyoming hunting guide [32] theorized that the mule deer in the Bridger Teton Wilderness declined from a healthy population in the early 1970's because they needed to migrate 100 miles over the Continental Divide or starve, "too high of a harvest of the older mature bucks results in the younger bucks not learning how to migrate back to the Jackson Hole side." Recent research on fish migrations [33] supports this idea that a loss of knowledge about migration routes from a loss of elders in the group can reduce survival.

More generally, Torres-Porras et al. [34] summarized some of the "published evidence for undesirable effects of biased population sex ratio and age structure" on deer populations. The researchers compared groups of deer in Spain under two different management regimes, one with balanced demographics and another with a female-biased population, reporting that "results indicate that this type of management may be unsustainable." A low buck-to doe ratio is commonly thought to spread out the time it takes to impregnate the does during the mating season, thereby spreading out the fawning season which gives predators more opportunities to take fawns - predators can only eat so many fawns at one time [35].

This line of research and the economic framework of Figure 2 suggest Hypothesis 5, that as a result of the negative effects from skewed herd demographics, states that have pursued this strategy the longest and in the most extreme will be farther from peak harvest.

H5: As a Result of Sex Ratio Management, the Percent of Peak Harvest Is Lower in States with More Extreme Buck Targets.

Analysis of the data described in the next section provides strong support for each of the hypotheses.

\section{Data Collection and Descriptive Statistics}

Data and hypotheses for this research were identified using a method often described in the business literature as environmental scanning, see Fahey and King [36]. Decker [37] describes how systematic internet searches, an environmental scanning approach, can be used to acquire business intelligence useful for market planning. For this research, the internet has been scanned on a daily basis for over four years with related information stored by topic and state to identify trends in deer management. Google Alerts, a freely available automated search tool, was configured to deliver daily search results for keywords related to deer management appearing on the internet during the previous 24 hour period, insuring capture of information that might be buried low on the list of search results of a less frequent search. Microsoft Bing was used to search the general term deer, also every 24 hours, to insure relevant information was discovered. Data collected through the internet search is available atwww.deerfriendly.com/decline-of-deer-populati ons.

The data discovered through this process used to explore the five hypotheses include: deer harvest data by state, deer hunter success by state, percent of bucks in the total deer harvest of each state, California timber sales from the from 1978 to 2012, and percent of public land in each state. Timber sales were obtained from the California State Board of Equalization [38]. Percent of public land in each state were taken from the Natural Resources Council of Maine [39].

Deer harvest data and hunter success rates for each state are typically available on the state wildlife agencies website. In some cases, the data has been taken from press releases. Harvest data up to the 2013-14 deer season were available for analysis in this research. Figure 3 shows the total deer harvest trend in the United States from the year 2000 to 2013. 
Hawaii has a small population of non-native deer and has a minimal annual deer harvest of around 500 so is excluded from most of this analysis. Of the 686 data points required to create Figure 3, there were 12 missing data points that were estimated using simple extrapolation methods.

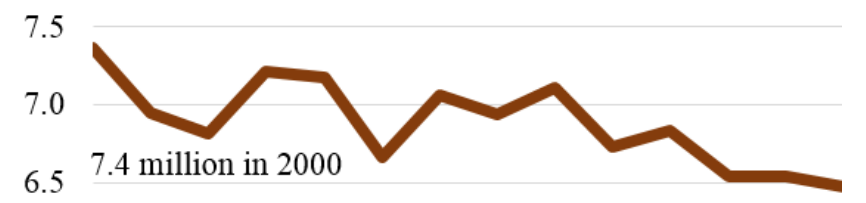

6.0

6.5 million in 2013

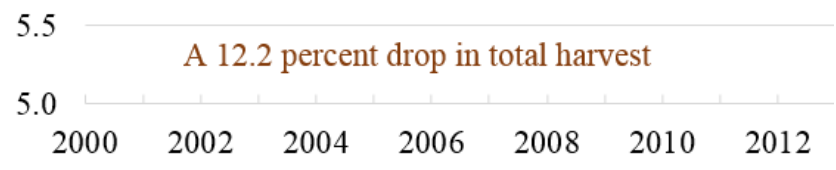

Source: State Wildlife Agency Reports and News Releases

Figure 3. Total Report U.S. Deer Harvest (Millions) 2000-2013

The downward harvest trend in Figure 3 suggests a downward trend in the U.S. deer population since the deer population approximately follows the harvest. Although deer population estimates are controversial, most states use some variation of the SAK (Sex-Age-Kill) model [40] which relies on the deer harvest (deer kill as it was more traditionally known) to estimate the population by adjusting for variations in the age and sex of the deer taken each year [41]. For example, a state agency may increase the number of tags for does to reduce a population that has become too large, a common method of controlling the deer population.

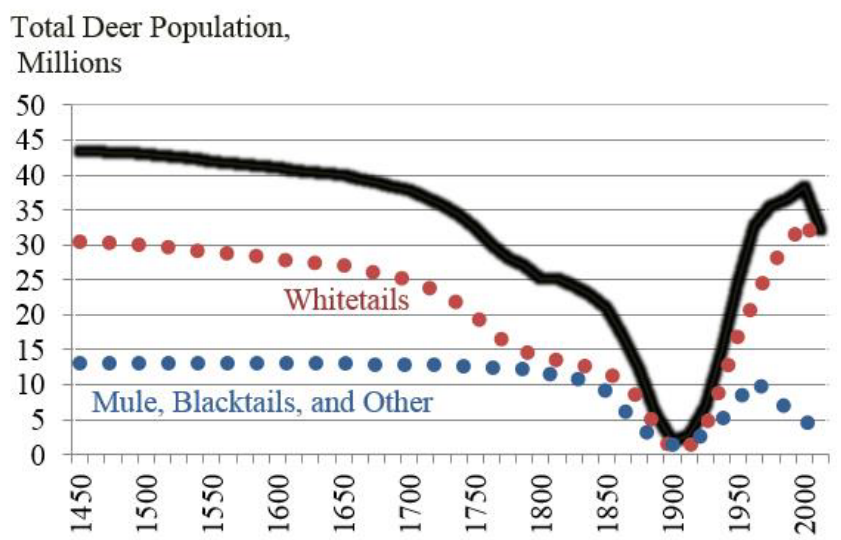

Figure 4. U.S. Deer Population 1450 to 2014

Based on recent public statements from state wildlife agencies about their total deer population, adjusted by making the simple assumption that the change in the deer harvest reflects the change in the total deer population, the total U.S. 2014 deer population is about 32.2 million - 28.6 million whitetails and 3.6 million mule deer, blacktails, and other deer. The recent peak U.S. deer population is estimated to have been around the year 2000 with about 38.1 million deer. Note that the deer of the western United States - mule deer, blacktails, and other - are well below their historic levels. Whitetails are declining but about at historic levels. From 2013 to 2014, the U.S. whitetail population fell by about 1.3 million deer. This analysis relies on extrapolating the deer populations back to 2000 using the percentage change in harvest data for each type of deer, so is an approximation. The whitetail deer trend from 2000 back to 1450 is based on VerCauteren [42], and McCabe \& McCabe [43]. The mule, blacktails, and other deer population from 2000 back to around 1910 is based on the deer harvest trends for those deer, although only a sample of harvest data is available over this period. The population prior to 1910 is based on a summary of historical opinions [44, 45]. The historical population estimates in Figure 4 are very approximate, but give an idea of the result of market hunting considered in these studies to be the main cause of the near extinction of deer in the United States by the early 1900's.

Recovery of deer varied dramatically by region with eastern states having a slower recovery. Recovery was faster in the west where surviving deer populations were generally higher in the early 1900's, but many western states saw deer populations peak in the 1960's and have experienced declines in their deer population for decades. California has had the most dramatic rise and fall in the harvest of any state over the past 100 years [46] - the pattern is illustrated in Figure 5.

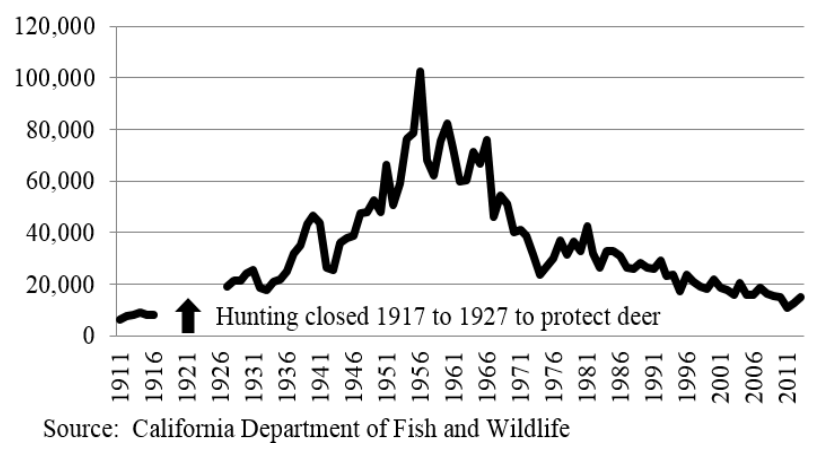

Figure 5. California Report Deer Harvest, 1911 to 2013

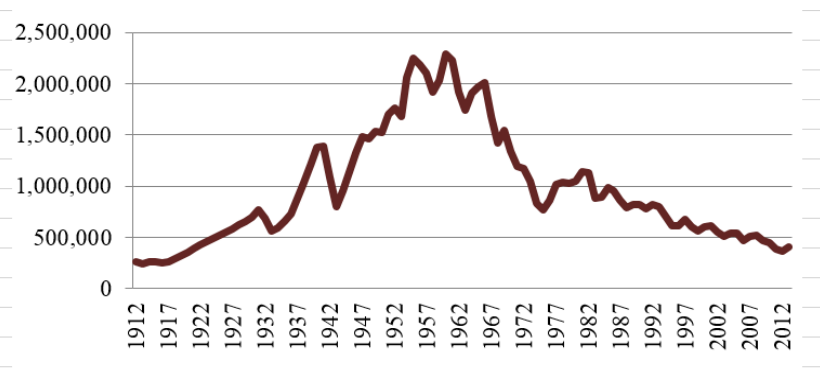

Estimated using a two-month moving average of the buck harvest divided by the median buck harvest-to-population ratio from 1991 to 2013 and for 1941.

Figure 6. Estimated California Population, 1912 to 2013

The spike in Figure 5, over a 100,000 deer harvested in 1956 , reflects the one year when does were a significant portion of the harvest, about 30 percent. For most of the other years, either no does were taken or they were only a small percentage of the total. In order to create an approximate historic deer population profile for California, Figure 6 
presents an estimate based on a two year moving average of the buck harvest divided by the historic buck harvest-to-population ratio available from the California Department of Fish and Wildlife on their website.

This approach described in Figure 6 follows that used by the states such as New Hampshire, New York, and West Virginia in making their state deer population estimate. Since there was no deer hunt from 1917 to 1927 , a linear trend was used to extrapolate the 1916 data to 1927.

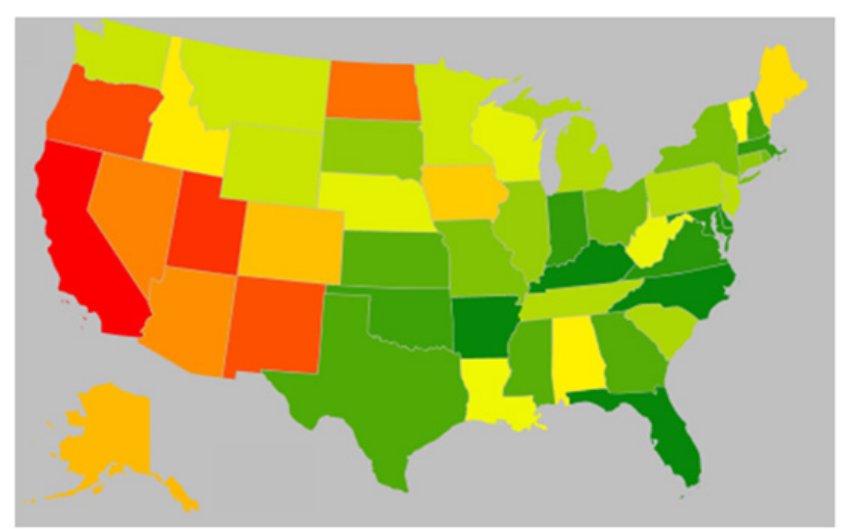

Source: State Wildlife Agency Reports and News Releases

Figure 7. 2013 Deer Harvest as a Percent of the Historical Peak Red Lower- Green Higher

As a measure of how effectively herds are being managed, data was collected from state wildlife agency reports and news releases about the historic peak deer harvest. Figure 7 provides of map of the state 2013 deer harvest as a percent of peak. Most states are currently trying to increase their deer herd, with a few states - less than five -- trying to reduce. Most states have a target deer population, although targets may change over time as there are various stakeholders involved in the population management decision process, some have conflicting goals.

As illustrated in Figure 8, the amount of public land in each state varies dramatically with western states generally having a larger percentage of public land. In order to test the idea that deer do better on public land, data was located at the Natural Resources Council of Maine reporting the percent of public land for each state.

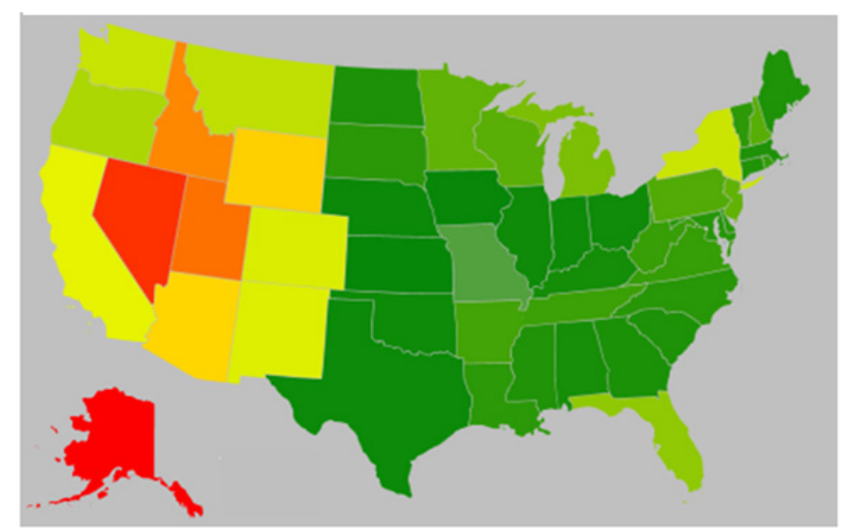

Source: Natural Resources Council of Maine

Figure 8. Percent of Public Land in East State Red Higher-Green Lower

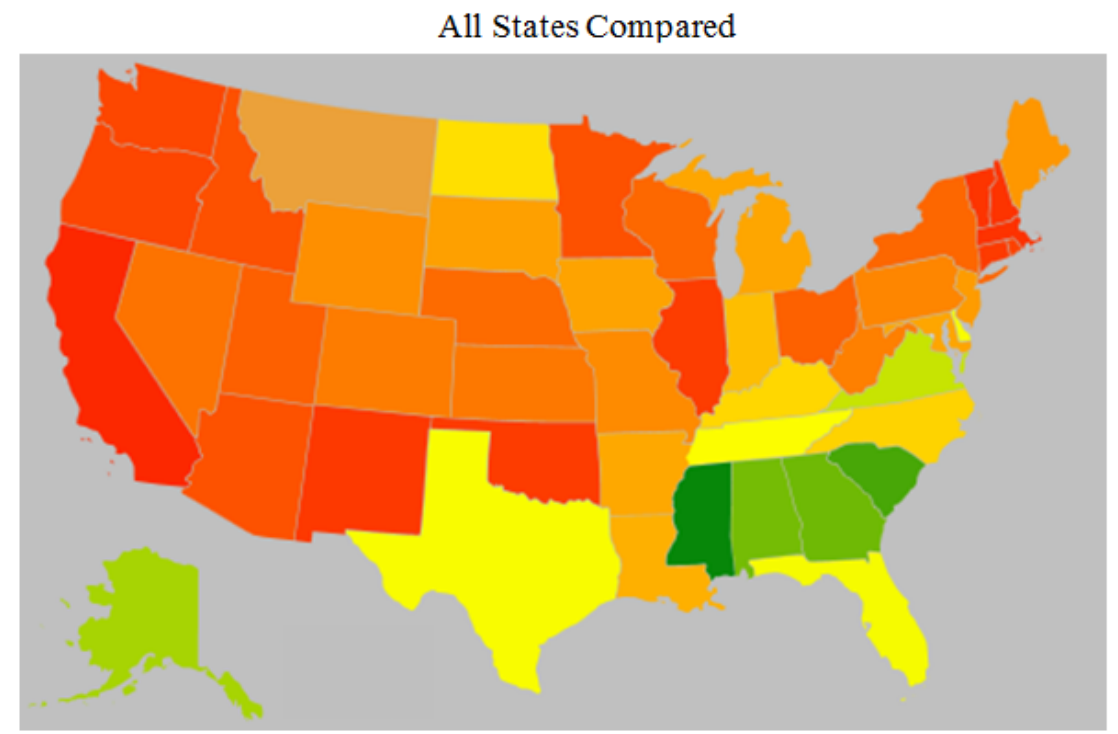

Western States Compared

Source: State Wildlife Agency Reports and News Releases.

Number of hunters for 3 states from Quality Deer Management

Figure 9. Deer Taken Per Hunter, 2013: Red Lower-Green Higher 
Hunter success is a common management goal for states and a measure of hunting pressure. Differences in how this number is calculated introduce some noise in the data. Some states calculate their success rate based on hunter reports, some based on survey. In many cases hunter success refers to the number of hunters that took at least one deer. For some states in the south the take is often well above one deer per hunter. In California most hunters get only one deer and the success rate in 2013 was 8 percent as reported by hunters or 17 percent as estimated by CDFW, the lowest reported success rate. Since for many states the percent of hunters taking one deer was not available, the number of deer taken per hunter is used in this analysis. Besides the advantage of availability, this ratio presumably offers a better measure of hunting pressure. There is a lot of red in Figure 9, illustrating the number of deer taken per hunter, given the very high ratios in the southeast. To facilitate a better visual analysis of the data, a comparison of the ratios using only western states is presented on the right of Figure 9.

The buck-to-doe management strategy as reflected in the percent of bucks taken in the hunt over the recent past is illustrated in Figure 10. In this case data was arranged in categories since this number may change from year to year as wildlife managers adjust the number of doe tags issues in an effort to manage the population. The category, "About 81 to $90 \%$ Bucks", for example, indicates that the buck harvest target as a percent of total harvest has generally been in this range for several years even though there might be a few outlying years. In the category "Over $90 \%$ bucks" all three states are close to 100 percent bucks as their harvest target.

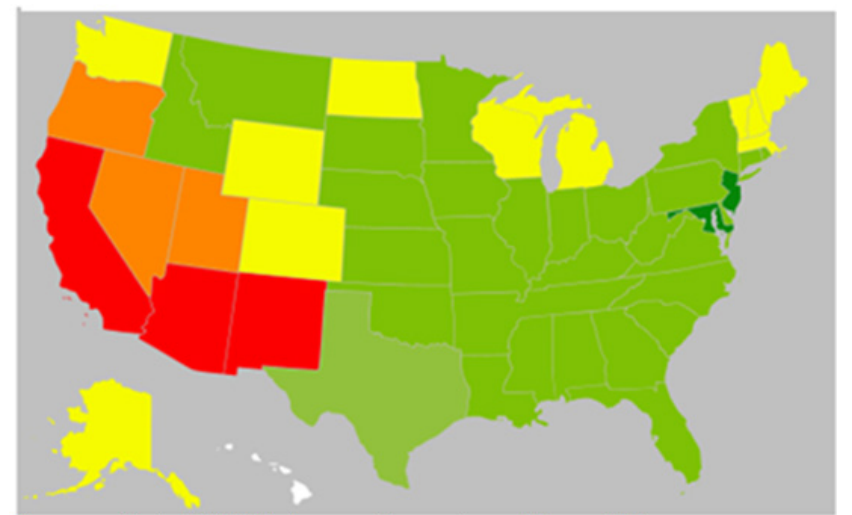

Source: State Wildlife Agency Reports and News Releases.

Figure 10. Long-term State Buck-to-Doe Hunting Strategy: Red, More than $90 \%$ Bucks. Orange, 81 to $90 \%$ Bucks. Yellow, 60 to $80 \%$ Bucks. Light green, Balanced. Dark Green, More Does than Bucks

Average values for each of the variables used in the analysis appear in Table 1 with variable values for the six states with the lowest 2013 harvest as a percent of the peak harvest. The year of the peak harvest (peak year) is also included, although this variable is not used in the analysis.

Table 1. States with the 2013 Harvest as the Lowest Percent of Peak Harvest

\begin{tabular}{|c|c|c|c|c|c|}
\hline State & $\%$ of Peak & Peak Year & Deer per Hunter & $\begin{array}{c}\text { \% Public } \\
\text { Land } \\
\end{array}$ & $\begin{array}{l}\text { Demographic Strategy } \\
\text { (over several years) }\end{array}$ \\
\hline $\mathrm{CA}$ & 13.8 & 1956 & $.08-0.17^{*}$ & 42.36 & Over $90 \%$ bucks \\
\hline UT & 22 & 1961 & 0.35 & 70.40 & About 81 to $90 \%$ bucks \\
\hline OR & 26 & 1961 & 0.26 & 31.58 & About 81 to $90 \%$ bucks \\
\hline NM & 27 & $1960 \mathrm{~s}$ & 0.23 & 40.62 & Over $90 \%$ bucks \\
\hline $\mathrm{ND} * *$ & 32 & 2006 & 0.77 & 4.95 & About 60 to $80 \%$ bucks \\
\hline NV & 35 & 1988 & 0.37 & 81.07 & About 81 to $90 \%$ bucks \\
\hline Average of all states & 66 & 1996 & 0.58 & 19.79 & \\
\hline Maximum & 100 & 2014 & 1.77 & 89.22 & \\
\hline Minimum & 13.8 & 1945 & 0.17 & 0.92 & \\
\hline
\end{tabular}




\section{Results}

The Relationship between the California Deer Harvest and Timber Sales

With regard to Hypothesis 1 (H1), that deer harvest will be positively correlated to timber sales; Table 2 presents the results of a linear regression analysis using data from California. The results show a very strong year to year positive relationship. The $\mathrm{R}$-square indicates that variations in timber sales alone account for about 55 percent of the variation in deer harvest with a P-value far below the 0.01 Type I error rate. The decline of the California deer population correlates closely with the decline in timber sales. The results show a very strong correlation of these two variables, suggesting a significant impact. Experimentation with alternative non-linear model formulations showed no improvement in the statistical results. For each of the following models, the following alternative formulations were evaluated using SPSS: linear, logarithmic, inverse, quadratic, cubic, power, compound, S, logistic, growth, exponential.

Table 2. California Deer Harvest Declines with Timber Sales

Dependent Variable: California Annual Deer Harvest, 1978 to 2012 R-square: 0.55

\begin{tabular}{|c|c|c|}
\hline Variable & Coefficient & P-value \\
\hline Intercept & 10,694 & 0.0000255 \\
\hline Timber Sales & 4.9 & 0.00000034 \\
\hline \multicolumn{2}{|c|}{ H1: Accepted at better than 0.01 level for California. } \\
\hline
\end{tabular}

Although it is understood on a more local scale that logging can improve deer habitat, especially when fires suppressions has allows forests to reach unnatural densities, the surprising strong relationship between the decline of deer harvests and the decline of timber sales provides good evidence that much of the decline in in the California deer population is driven by degraded habitat. Some states, such as Utah, have made significant investments in habitat restoration in recent years in order to address this problem. In California, decision making about deer management and forest management is largely separated, making it difficult to coordinate strategies.

\section{Deer Do Better on Public Land?}

With regard to Hypothesis $2(\mathrm{H} 2)$ that deer do better on public land, Table 3 presents the results of an analysis of 49 states (Hawaii excluded, no native deer) showing that the 2013 deer harvest was farther below peak harvest in states with a higher percent of land owned by state or federal agencies. The P-value is well below the 0.01 level, suggesting a strong correlation. The linear model slightly outperformed alternatives, the next best fit being the logistic then exponential. The Durbin-Watson statistic, close to 2, suggests an approximately linear relationship.

Deer are managed in the United States under the general policy umbrella of the North American Model of Wildlife
Conservation with the general idea that the deer belong to the people of each state and are managed by stage agencies on behalf of the people. Support for this policy dates back to the reasons for the Revolutionary war in the late 1700's, a reaction against the policy of the United Kingdom that deer were owned by the king or landowners.

Table 3. Percent of Peak Harvest Is Lower in States with a Higher Percent of Public Land

\begin{tabular}{|c|c|c|}
\hline \multicolumn{3}{|c|}{$\begin{array}{c}\text { Dependent: } 2013 \text { Deer Harvest as a Percent of Peak Harvest } \\
\text { Independent: Percent of Public Land } \\
\text { R-square }=0.32 ; \mathrm{F}=22.71 ; \mathrm{P}=0.00002\end{array}$} \\
\hline Linear Model & Coefficient & P-value \\
\hline Intercept & 0.7902 & $3.2 \mathrm{E}-26$ \\
\hline Percent Public & -0.581 & 0.00002 \\
\hline \multicolumn{3}{|c|}{$\begin{array}{c}\text { H2: Accepted better than } 0.01 \text { level. } \\
\text { Dubin-Watson }=2.23 . \mathrm{DF}=47\end{array}$} \\
\hline Alternative & $\mathrm{F}$ & P-value \\
\hline Logistic & 22.511 & 0.00004 \\
\hline Exponential & 22.511 & 0.00004 \\
\hline
\end{tabular}

The North American Model of Wildlife Conservation has been eroding in recent years, particularly in Texas which has moved toward a more mixed private/public model. There has also been a slow, but steady move in many states farmed deer are classified as livestock, managed by the Department of Agriculture rather than the Department of Natural Resources. This result indicates that there are some chinks in the armor of the North American Model and that a review of the efficacy of this approach is in order. As suggested by the economic model presented earlier, the current public management approach appears to encourage under investment in habitat and over hunting. This conclusion would particularly apply to states colored yellow to red in Figure 8 , states with a large percentage of public land. These states are located primary in the west where the decline of mule and blacktail deer populations has been going on for decades.

Is Hunting Pressure Higher in States With More Public Land?

The economic model presented earlier also suggests that public managers are incentivized to issue too many deer tags, increasing hunting pressure, and possibly reducing the herd by over hunting. In order to standardize the measure of hunting pressure, data was collected from each state for the number of deer taken per hunter. Although many states report hunter success as the percent of hunters taking one deer, not all states report this number and the number of deer allowed to be taken varies by state. As a result, this measure was chosen as a more consistent measure of hunting pressure.

With regard to Hypothesis 3 (H3), that hunter the number of deer taken per hunter will be lower on states with more public land, the P-value for the linear relationship is above the 0.05 probability for a type I error. However, an examination of the residuals errors, done for each of these 
analyses, reveals an exception in Alaska with lots of public land but high deer per hunter ratio. This may be the result of a difference in management policy. Adding a dummy variable to account for the situation in Alaska improves the statistical fit, reducing the P-value to 0.022 as reported in Table 4 -- significant support for Hypothesis 3. Some experiments in using non-linear specifications of this relationship reported in Table 4 give even higher levels of significance.

This result gives support to the observations of many that deer tend to be over hunted on public land. State agencies face political pressure to keep hunting license fees low and pricing is typically not at the discretion of the deer managers, but a different set of decision makers. A policy in Missouri that has successfully addressed this issue to some extent has been a conservation sales tax to support forests and wildlife, reducing dependence on hunting license fees. As deer populations and hunting participation decline in the future, hunting license revenues are likely to decline, exacerbating this problem. As many involved in wildlife management policy are aware, finding new sources of support present an important challenge for the future.

Table 4. Number of Deer per Hunter Lower on State with More Public Land.

\begin{tabular}{|c|c|c|}
\hline \multicolumn{3}{|c|}{$\begin{array}{c}\text { Dependent: Number of Deer per Hunter } \\
\text { Independent: Percent Public Land } \\
\text { R-square }=0.161 ; \mathrm{F}=4.417 \mathrm{P}=0.018\end{array}$} \\
\hline Linear Model & Coefficient & P-value \\
\hline Intercept & 0.675 & 0.000 \\
\hline Public & -0.597 & 0.022 \\
\hline Alaska & 1.047 & 0.011 \\
\hline $\begin{array}{c}\text { Hypothesis 3 accepted at better than 0.05 level with Alaska showing } \\
\text { variation in public management. Lots of public land and high number of } \\
\text { deer per hunter. Durbin Watson: 2.138 }\end{array}$ \\
\hline $\begin{array}{c}\text { Alternative (not } \\
\text { including Alaska } \\
\text { variable) }\end{array}$ & $\mathrm{F}$ & P-value \\
\hline Quadratic & 3.7500 & 0.031 \\
\hline Cubic & 3.107 & 0.036 \\
\hline
\end{tabular}

Does Greater Hunting Pressure Translate in Reduce Deer Harvests?

As a policy issue, the conclusion in the previous section is that increased hunting pressure in states with more public land policy incentivizes over hunting. In order to test the proposition that this increased hunting pressure will translate into reduced deer harvests resulting from over hunting; Hypothesis $4(\mathrm{H} 4)$ proposes that the percent of peak deer harvest will be lower in states with lower deer per hunter. Low hunter success rates are thought to be a common symptom of issuing too many tags. For example, California typically has the lowest number of deer per hunter and has also experienced the largest decline in the deer harvest. States routinely adjust their tag allocations to control hunter success and hunting pressure.

Table 5 shows that the data support this hypothesis with a
P-value of less than 0.000. In this case, an S-curve provides the best fit of the data. A graphical examination of the data reveals that the percent of peak harvest rapidly increases with deer per hunter from the lowest levels, and then levels off at around 0.5 deer per hunter. States falling much below about 0.5 deer per hunter appear to be issuing enough tags that deer populations are showing evidence of excessive hunting pressure. As a policy consideration, states falling into this category may want to evaluate their tag allocation goals. These states are identified as red in Figure 9. Given the very high number of deer taken per hunter in some southeastern states, only states near the red end of the scale are much below this target. The right side of Figure 9 maps a comparison of western states where the deer declines have been more severe. States that neighbor California report a higher number of deer taken per hunter and have had more modest declines in their deer population. In 2014 California issued approximately 2 buck hunting tags for every available buck in the state.

Table 5. The Percent of Peak Harvest Trends Lower in States with Lower Number of Deer per Hunter

\begin{tabular}{|c|c|c|}
\hline \multicolumn{3}{|c|}{$\begin{array}{l}\text { Dependent: } 2013 \text { Deer Harvest as Percent of Peak Harvest } \\
\text { Independent: } 2013 \text { Deer per Hunter } \\
\text { R-square }=0.248 ; \mathrm{F}=15.507 ; \mathrm{P}=0.000\end{array}$} \\
\hline S-curve & Coefficient & P-value \\
\hline Constant & -0.174 & 0.000 \\
\hline Deer Per Hunter & -0.117 & 0.000 \\
\hline Alternative & $\mathrm{F}$ & P-value \\
\hline Power & 8.7 & 0.005 \\
\hline Inverse & 8.018 & 0.007 \\
\hline Logistic & 4.242 & 0.045 \\
\hline Linear & 3.819 & 0.057 \\
\hline
\end{tabular}

Are Long-term High Buck Harvests Associated with Reduced Deer Populations?

In the short-term, states routinely adjust the doe harvest as a method of controlling the population. Harvesting more bucks than does leaves a larger breeding population in the field. Each buck can impregnate many does. However, the earlier literature review referenced some studies and other observations about the potential negative impact of relying on a long-term strategy of maintaining a harvest highly skewed toward bucks, skewing the demographic makeup of the herd. While this approach appeared to work in the early to mid-1900s when deer populations were well below the levels that habitat could support, the literature suggests that there are potential problems when deer are also hampered by habitat limitations or other pressures.

The results presented in Table six support Hypothesis 5(H5), that the Percent of Peak Harvest is Lower in States with More Extreme Buck Harvests. This equation is set up as a dummy variable analysis with the comparison variable (the intercept) being the states using a balanced approach, about the same number of bucks and deer in the harvest. The estimated coefficient for the Balanced (Intercept) variable is 
0.774 and indicates that in states with a balanced harvest the 2013 harvest was about 77.4 percent of the peak harvest. The estimated coefficients show taking more bucks in the harvest over the long run is correlated with a lower 2013 harvest as a percent of peak. Although deer managers often reduce doe tags for a few years to boost the population, the data suggest there may be a long-run negative effect associated with this practice.

Definitions for the variable categories are based on the percentage of bucks in the harvest over the recent past 10 to 15 years. A few states are in the "Less" category, taking more does than bucks in an effort to reduce the population. The "More" category represents states taking about 81 to 90 percent bucks. 'Most" refers to 60 to 80 percent bucks. Three states fit into the "Only" category, taking over $90 \%$ bucks: California, Arizona, and New Mexico. Arizona, has conducted a buck only hunt since the year 2000. New Mexico has been buck only since 1983, but has used antler restrictions since 2000 to protect older bucks. Except for a few years around 1956 and the early 1960's, California has been virtually a buck only hunt for nearly the past 100 years. No other state has pursued this policy as long as California, the state with the lowest 2013 harvest as a percent of peak harvest. California has limited antler restrictions; about half the deer taken in the hunt are two point bucks, higher than the average for most states and perhaps further skewing the herd demographics.

Table 6. Percent of Peak Harvest is lower in States with More Extreme Buck Harvests

\begin{tabular}{|c|c|c|}
\hline \multirow{2}{*}{\multicolumn{3}{|c|}{$\begin{array}{l}\text { A dummy variable regression using balanced herd demographic } \\
\text { comparison variable, the intercept in this output, for states takin } \\
50 \text { percent each bucks and does } \\
\text { Dependent: } 2013 \text { Deer Harvest as a Percent of Peak } \\
\text { R-square }=0.551 ; \mathrm{F}=13.505 ; \text { P-value } 0.000 \\
\text { Durbin-Watson } 2.041\end{array}$}} \\
\hline & & \\
\hline Linear & Coefficient & P-value \\
\hline Constant & 0.774 & 0.000 \\
\hline Only & -0.515 & 0.000 \\
\hline Most & -0.497 & 0.000 \\
\hline More & -0.170 & 0.004 \\
\hline Less & 0.036 & 0.759 \\
\hline Alternative & $\mathrm{F}$ & P-value \\
\hline Logit & 11.117 & 0.000 \\
\hline
\end{tabular}

A trend of modern deer management has focused on the concept of balanced demographics for herd health. Many states have moved to this approach. One reason that California may not have followed this trend is that while wildlife biologists make recommendations about the number of doe tags that can be issued, the final policy decisions are actually made by county government officials. Deer managers in many states have had a hard time convincing hunters to take a larger proportion of does in the harvest and efforts to balance herd demographics have sometimes been less successful than hoped because of resistance from hunters. In California, the old adage that reducing the doe harvest will promote herd growth seems to be so ingrained in the system, that the state is unable to adopt more modern concept of deer management. Based on this result, states in Figure 10 identified as being in the orange and red end of the scale may be damaging herd health by pursuing a skewed buck to doe ratio.

\section{Conclusions}

Some restrictions on logging that have reduced timber sales appear to have contributed to the decline of deer populations, at least in California which has experienced the largest decline from peak harvest. It is commonly observed that forest management practices, such as fire suppression and other practices allowing the maturation of forests, have a negative impact on populations of edge dependent species such as deer. Pricing policies for deer tags may be a factor contributing to a misallocation of resources that is evidenced in the trend of states with more public land to have a lower percent of peak harvest and a trend of more hunting pressure as measured by hunting success.

Revenue loss in general from below market prices for hunting licenses may be discouraging adequate investment in habitat management and more reliance on skewed buck to doe ratios to maintain deer populations. Over population of deer that has occurred in the past and still persists in some regions has been associated with artificially inflating populations by limiting the number of does taken in the hunt. California has followed this policy in the extreme for nearly a hundred years. It appears that this strategy may have a negative impact on deer populations in the long-run.

States restricting doe harvests over a long period of time tend to be farther from peak population than states with more balanced demographic strategies - the distance from peak harvest increases as the percent of bucks in the harvest increases. Much of modern deer management is focused on balancing herd demographics, age and sex. The detrimental effects of these skewed demographics have been documented in the wildlife management literature.

Results of the hypothesis tests in this study are summarized in the Table 7 below. In the case of H3, Alaska was identified as an exception to the relationship of more hunting pressure in states with more public land.

Table 7. Summary of Results from Hypothesis Tests

\begin{tabular}{|l|c|}
\hline \multicolumn{1}{|c|}{ Hypothesis } & Result \\
\hline $\begin{array}{l}\text { H1: Is the California Deer Harvest Positively Correlated to } \\
\text { Timber Sales }\end{array}$ & Yes \\
\hline H2: Deer Do Better on Public Land? & Yes \\
\hline $\begin{array}{l}\text { H3: Is Hunting Pressure Higher in States With More Public } \\
\text { Land? }\end{array}$ & Yes \\
\hline $\begin{array}{l}\text { H4: Does Greater Hunting Pressure Translate in Reduce } \\
\text { Deer Harvests? }\end{array}$ & Yes \\
\hline $\begin{array}{l}\text { H5: Are Long-term High Buck Harvests Associated with } \\
\text { Reduced Deer Populations? }\end{array}$ & Yes \\
\hline
\end{tabular}


Cross sectional analysis of state policies can provide a useful way to evaluate their impacts. Based on the extensive literature search done for this paper, it appears that this is the first analysis of differences in deer harvest using data from each of the states, Hawaii excluded. Given the increasing use of the internet by states agencies to make this type of information publically available, the effort required to gather this data has been greatly reduced in recent years. Still, differences in data collection methods and data definitions add some noise into the analysis. Significant effort has been made in this study to mitigate the noise by defining variables as percentage change and ratios, using data available in all of the states.

Future research in this area could include work to development more sophisticated equations systems to investigate these issues. Also, the data could be used to more generally evaluate differences among other states, not just a focus on a comparison to California, with policy recommendations for groups of states. To support this type of analysis, the data related to state deer management and statistics used in this study have been made publically available in one location at www.deerfriendly.com/declineof-deer-populations. The author hopes that availability of this data will encourage future research efforts that have before seemed infeasible because of limited data availability.

\section{REFERENCES}

[1] U.S. Fish and Wildlife Service, U.S. Department of the Interior, and U.S. Department of Commerce. 2011 national survey of fishing, hunting, and wildlife-associated recreation," FHW/11-NAT (RV), 2014. Available from: https://www.cen sus.gov/prod/2012pubs/fhw11-nat.pdf

[2] Sanders J. Support legislation to preserve our hunting heritage. The Orange Leader. 2015 March. Available from: http://www.orangeleader.com/opinion/support-legislation-topreserve-our-hunting-heritage/article_298173a6-d28c-11e4af8e-fbbf26035b64.html

[3] Webb GK. Results of environmental scanning applied to the design of a deer management decision support system (DSS) for the United States and California. Issues in Information Systems [Internet]. 2014; 15(2): 77-88. Available from: http://iacis.org/iis/2014/92_iis_2014_77-88.pdf

[4] Drehle DV. America's pest problem: it's time to cull the herd. Time Magazine. 2013 December 9; p. 38.

[5] Ballard WB, Lutz D, Keegan TW, Carpenter LH, and James C. deVos, Jr. JC. Deer-Predator Relationships: A Review of Recent North American Studies with Emphasis on Mule and Black-Tailed Deer. Wildlife Society Bulletin. 2000; 29(1): 99-115.

[6] Carpenter LH. Deer in the West. In: Proceedings of the 1997 Deer/Elk Workshop; 1997; Rio Rico, Arizona. Arizona Game and Fish Department, Phoenix, USA; c1998. p. 1-10.

[7] Garton EO, Heady HF, Connolly GE. The California deer decline and possibilities for restoration. Transactions of the
Western Section of the Wildlife Society. 1976; 12:74-103.

[8] Richards H. Game and Fish search for solutions to muley decline. Buffalo Bulletin [Internet]. 2015 February 4. Available from: http://www.buffalobulletin.com/article 75b 5135a-acbb-11e4-9722-33adce5b0af2.html

[9] Mallicoat D. U.S. Forest Service slaps hunters in the face. The Tribune [Internet]. 2015 March 21. Available from: http://www.thetribunepapers.com/2015/03/21/u-s-forest-serv ice-slaps-hunters-in-the-face/

[10] Higley J. Deer-friendly forests. Game\&Fish \{Internet]. 2010 September 29. Available from http://www.gameandfishmag. com/hunting/hunting_mule-deer-blacktail-deer-hunting_ca_a a110703a/

[11] Carlson PC. Tanner GW. Wood JM. Humphrey SR. Fire in key deer habitat improves browse, prevents succession, and preserves endemic herbs. The Journal of Wildlife Management. 1993; 57(4):914-928.

[12] Clements CD. and Young JA. A viewpoint: rangeland health and mule deer habitat. Journal of Range Management. 1997; 50(2):129-138

[13] Kelker GH. Computing the rate of increase for deer. The Journal of Wildlife Management. 1947; 11(2):177-183.

[14] Lowe, PO. Folliott PF. Dieterich JH. David R. Patton DR. Determining potential wildlife benefits from wildlife in Arizona Ponderosa Pine. In: 1978 General Technical Report RM-52, Rocky Mountain Forest and Range Experiment Station. US Department of Agriculture Forest Service. Fort Collins, CO. 1978.

[15] Storer TI. Factors influencing wild life in California, past and present. Ecology 1932; 13(4) October: 315-327.

[16] Heyman IM. Twiss RH. Environmental management of the public lands. Ecology Law Quarterly. 1971; 1(1):94-142.

[17] Weber BA. Chen Y. Federal forest policy and community prosperity in the Pacific Northwest. Choices: The Magazine of Food, Farm, and Resource Issues, 2012; 27(1). Available from: http://ageconsearch.umn.edu/handle/122803

[18] Aleshire I. BLM halts logging near Shotgun Creek. The Register-Guard. 2015 March 25. Available from: http://registerguard.com/rg/news/local/32907284-75/blm-put s-timber-harvest-near-shotgun-creek-on-hold.html.csp\#.VRIl xLVJ5kA.twitter

[19] Wyogoob. Deer Migration in Wyoming. 2014 May 24 posting on UtahWildlife.net. Available at:http://utahwildlife.net/foru $\mathrm{m} / 12$-big-game/81570-deer-migration-wyoming-2.html

[20] Sandrey RA. Buccola ST. Brown WG. Pricing policies for antlerless elk hunting permits. Land Economics. 1983; 59(4):432-443

[21] Hussain A. Tanvir M. Tschirhart J. Optimal harvest licensing when harvest success is uncertain. American Journal of Agricultural Economics. 2010; 92(1):125-140

[22] Roach B. Loomis J. Motroni R. Economic analysis of deer management on public lands in northern California. Human Dimensions of Wildlife. 1996; 1(2):14-23.

[23] Dovel, G. Mule Deer Management in Idaho. The Outdoorsman. 2004 October-November: 1-13. 
[24] Curtis J. Lynch L. Explaining deer population preferences: an analysis of farmers, hunters and the general public. Agricultural and Resource Economics Review. 2001; $30(1): 44-55$

[25] Prettyman B. Antelope ssland trophy mule deer tag draws world record bid of $\$ 390,000$. Where does all that money go?' Salt Lake Tribune. 2015 February 23. Available at: http://www.sltrib.com/home/2212820-155/antelope-island-tr ophy-mule-deer-tag

[26] Pope CA. III, Stoll JR. The market value of ingress rights for white-tailed deer hunting in Texas. Southern Journal of Agricultural Economics. 1985 July: 177-182.

[27] Knoche S. Lupi F. Valuing deer hunting ecosystem services from farm landscapes. Ecological Economics. 2007; 64(2):313-320.

[28] Shrestha RK. Alvalapati JRR. Effect of ranchland attributes on recreational hunting in Florida: a hedonic price analysis Journal of Agricultural and Applied Economics. 2004; 36(3):763-772.

[29] Zhang D. Hussain A. and James B. Armstrong JB. Willingness to Pay for Hunting Leases in Alabama. Southern Journal of Applied Forestry. 2004; 28(1):21-27.

[30] Richter AR. Labisky RF. Reproductive dynamics among disjunct white-tailed deer herds in Florida. The Journal of Wildlife Management. 1985; 49(4):964-971.

[31] Reilly, P.J. (2012). Trophy minded: is trophy hunting hurting our sport. Bowhunting.com, 2012 September 23. Available at: http://www.bowhunting.com/blog/2012/9/23/trophy-mindedis-trophy-hunting-hurting-our-sport/

[32] Eastman M. Northern Wyoming mule deer migration. EastmansBlog.com. 2015. Available at: http://blog.eastmans. com/northern-wyoming-mule-deer-migration-2/

[33] DeLuca G. Mariani P. MacKenzie BR.Marsili M. Fishing out collective memory of migratory schools. Journal of the Royal Society Interface. 2014; 11(95). Available at: http://rsif.royalsocietypublishing.org/content/11/95/2014004 3

[34] Torres-Porras J, Carranza J, Pérez-González J, Mateos C, Alarcos S. The tragedy of the commons: unsustainable population structure of Iberian red deer in hunting estates. European Journal of Wildlife Research. 2014 Apr $1 ; 60(2): 351-7$.
[35] Kornegay B. Balanced deer herd takes time and perseverance. The Albany Herald. 2014 November 15. Available at: http://www.albanyherald.com/news/2014/nov/15/balanced-d eer-herd-takes-time-and-perseverance/?sports

[36] Fahey L. King WR. Environmental scanning for corporate planning. Business Horizons. 1977; 20(4):61-71.

[37] Decker R. Wagner R. Scholz SW. An internet - based approach to environmental scanning in marketing planning. Marketing Intelligence \& Planning, 2005; 23(2):189-199.

[38] California State Board of Equalization. California Timber Harvest Statistics. Available at: http://www.boe.ca.gov/propt axes/pdf/harvyr2.pdf.

[39] Natural Resources Council of Maine. Public Land Ownership by State. Available at: http://www.nrcm.org/documents/publ iclandownership.pdf

[40] Millspaugh JJ. Skalski JR. Townsend RL. Dieffenbach DR. Boyce MS. Hansen LP. Kammermeyer K. An evaluation of sex-age-kill (SAK) model performance. The Journal of Wildlife Management. 2009; 73:442-451.

[41] McCoy J. W.Va wildlife biologists calculate deer numbers to set hunting regulations. WVGazette.com. 2015 January 31. Available at: http://www.wvgazette.com/article/20150131/G Z07/150139885

[42] VerCauteren K. The deer boom: discussions on population growth and range expansion of the white-tailed deer. USDA National Wildlife Research Center - Staff Publications. Paper 281, 2003. Availableat: .http://digitalcommons.unl.edu/cgi/v iewcontent.cgi article $=1276 \&$ context $=\mathrm{icwdm}$ usdanwrc

[43] McCabe RE. and Thomas R. McCage TR. Of slings and arrows: an historical retrospection. In Halls LK. White-tailed deer: ecology and management. Harrisburgy, PA: Stackpole Books. 1984. p. 19-72.

[44] Davenport L. U.S. deer herds in trouble. Mother Earth News. 2014 September 17. Available at: http://www.motherearthne ws.com/nature-and-environment/us-deer-herds-in-trouble-zb cz1409.aspx\#axzz3DaQ5AOOa

[45] Terry M. Mule deer's plight and peril: a true story. Kingscamo. 2012. Available at:http://my.kingscamo.com/2012/about-mu le-deer-plight-peril/

[46] Webb GK. Results of environmental scanning applied to the design of a deer management decision support system (DSS) for the United States and California. Issues in Information Systems. 2014; 15(2):77-88 